McKersie, B.D., J.R. Lepock, J. Kruuv, and J.E. Thompson. 1978. The effects of cotyledon senescence on the composition and physical properties of membrane lipids. Biochim. Biophys. Acta 508:197-212.

McKersie, B.D. and J.E. Thompson. 1979. Phase properties of senescing plant membranes. Role of neutral lipids. Biochim. Biophys. Acta 550:48-58.

Pauls, K.P. and J.E. Thompson. 1984. Evidence for the accumulation of peroxidized lipids in membranes of senescing cotyledons. Plant Physiol. 75:1152-1157.

Platt-Aloia, K. and W.W. Thomson. 1985. Freeze-fracture evidence of gelphase lipid in membranes of senescing cowpea cotyledons. Planta 163:360369.

Tappel, A.L. 1975. Lipid peroxidation and fluorescent molecular damage to membranes, p. 145-170. In: B.F. Trump and A. Arstila (eds.). Pathobiology of cell membranes. Academic, New York.

Thompson, J.E., R.L. Legge, and R.F. Barber. 1987. The role of free radicals in senescence and wounding. New Phytol. 105:317-344.

Thompson, J.E., S. Mayak, M. Shinitzky, and A.H. Halevy. 1982. Acceleration of membrane senescence in cut carnation flowers by treatment with ethylene. Plant Physiol. 69:859-863.
Wilhelm, J. and N. Wilhelnova. 1981. Accumulation of lipofuscin-like pigments in chloroplasts from senescent leaves of Phaseolus vulgaris. Photosynthetica 15:55-60.

Wray, W.W., T. Bovikas, V.P. Wray, and R. Hancock. 1981. Silver staining of proteins in polyacrylamide gels. Anal. Biochem. 118:197-203.

Yao, K., G. Paliyath, R.W. Humphrey, F.R. Hallett, and J.E. Thompson. 1991a. Identification and characterization of nonsedimentable lipid-protein microvesicles. Proc. Natl. Acad. Sci. USA 88:2269-2273.

Yao, K., G. Paliyath, and J.E. Thompson. 1991b. Nonsedimentable microvesicles from senescing bean cotyledons contain gel phase-forming phospholipid degradation products. Plant Physiol. 97:502-508.

Yao, K., G. Paliyath, and J.E. Thompson. 1993a. Localization of peroxidized lipids in nonsedimentable microvesicles of senescing bean cotyledons. J. Expt. Bot. 44:1267-1274.

Yao, K. and J.E. Thompson. 1993. Enrichment of proteinase activity in deteriosomes, a new class of microvesicles. FEBS Lett. 323:99-103.

Yao, K., X. Wu, J.E. Thompson, and J.C. Carlson. 1993b. Isolation and characterization of deteriosomes from rat liver. J. Cell Physiol. 51:488-494.

\title{
Toward a Comprehensive Model for Lipid Peroxidation in Plant Tissue Disorders
}

\author{
Robert L. Shewfelt \\ Center for Food Safety and Quality Enhancement, University of Georgia, Griffin, GA 30223-1797 \\ Albert C. Purvis \\ Department of Horticulture, Coastal Plain Station, University of Georgia, Tifton, GA 31793
}

Lipid peroxidation has been observed during the development of metabolic disorders in plant (Shewfelt and Erickson, 1991; Winston, 1990) and animal tissues (Kehrer, 1993; Pacifici and Davies, 1991). A partial list of recent reports linking lipid peroxidation to plant disorders, senescence, and aging is shown in Table 1. It is not clear whether peroxidation represents a primary cause or merely a secondary effect of these disorders. Lipid peroxidation and associated defense mechanisms in the cell occur via an exceedingly complex process. While certain steps appear to be nonenzymic chemical reactions governed strictly by kinetics (Buettner, 1993), others are clearly under genetic control (Kane et al., 1993). Statements to proclaim or dismiss lipid peroxidation as the primary cause of these disorders have been based on oversimplification of the processes involved. The case against a causative role is based on the variability of cell and tissue response to various types of stress and the frequent lack of evidence of peroxidative product accumulation before onset of the disorder (see Table 2 for recent examples). The objective of this review is not to catalog lipid oxidation in plant stresses, but to provide a framework for evaluating a cause-and-effect relationship in these disorders. This article presents an overview of peroxidative processes in plant tissues, a comprehensive model to explain how peroxidation of membrane lipids could function to cause disorders, specific explanations for problematical observations of affected tissue, and implications of the model if the theory is correct. The proposed model is an amplification and extension of one described earlier (Purvis and Shewfelt, 1993; Shewfelt and Erickson, 1991).

\section{PEROXIDATION IN PLANT TISSUE}

Lipid peroxidation is a natural consequence of metabolic processes in the cell, occurring via initiation, propagation, and termination reactions (Schaich, 1992; Winston, 1990). Active oxygen species such as superoxide $\left(\mathrm{O}_{2}^{-}\right)$and hydrogen peroxide $\left(\mathrm{H}_{2} \mathrm{O}_{2}\right)$ are by-products of

The cost of publishing this paper was defrayed in part by the payment of page charges. Under postal regulations, this paper therefore must be hereby marked advertisement solely to indicate this fact. electron transport in chloroplasts, mitochondria, and plasma membranes (Winston, 1990). Interaction of superoxide and hydrogen peroxide with iron species $\left(\mathrm{Fe}^{2+}, \mathrm{Fe}^{3+}\right)$ in membranes leads to formation of lipid-free radicals, presumably via formation of the hydroxyl radical (HO.) (Borg and Schaich, 1988) or by an iron intermediate that is most active as the $\mathrm{Fe}^{2+}: \mathrm{Fe}^{3+}$ ratio approaches 1.0 (Minotti and Aust, 1992). Singlet oxygen $\left({ }^{1} \mathrm{O}_{2}\right)$ is formed in chloroplasts during photosynthesis (Chakraborty and Tripathy, 1992) and is highly reactive with lipids (Bradley and Min, 1992).

Lipid hydroperoxides ( $\mathrm{LOOH})$ are also formed in plant tissue by lipoxygenase (LOX) (Gardner, 1991). Unlike the free radical processes described above, lipoxygenase, acting under aerobic conditions, does not produce lipid-free radicals. In addition, lipoxygenases in plant tissue either require or preferentially attack free fatty acids (Hildebrand, 1989), usually acting in concert with hydrolytic enzymes (Leshem, 1992).

For each source of lipid peroxidation within the cell there is a defense mechanism. Thus, superoxide can be degraded to hydrogen peroxide by superoxide dismutase (SOD) and hydrogen peroxide can be further degraded to water and oxygen by catalase. Alpha-tocopherol, $\beta$-carotene, and ascorbic acid will scavenge free radicals, including the hydroxyl radical (Buettner, 1993), while carotenoids (DiMascio et al., 1989) and ubiquinone (Cabrini et al., 1986) quench singlet oxygen. Lipoxygenase activity is controlled by compartmentation (Elstner, 1991) and by maintaining the fatty acids in the esterified form (Hildebrand, 1989).

Despite the presence of defense systems, membrane lipids are peroxidized, probably via generation of the hydroxyl radical in the membrane in close proximity to a polyunsaturated fatty acid (PUFA). The resultant lipid peroxyl radical will be quickly converted to a lipid hydroperoxide by interaction with $\alpha$-tocopherol or other hydrogen donors (Fig. 1) (Buettner, 1993). One $\alpha$-tocopherol molecule is estimated to protect from 220 (Cogrel et al., 1993) to 1000 (Buettner, 1993) phospholipid molecules within a membrane. Rapid mobility of $\alpha$-tocopherol in the bilayer is achieved by the association of its polar head group with the polar head group of phosphatidylcholine (PC) (Urano et al., 1993). The tocopheroxyl radical is more stable than a 


\section{WORKSHOP}

Table 1. Recent references supporting a link between lipid peroxidation and plant tissue disorders or senescence and aging.

\begin{tabular}{|c|c|c|}
\hline Inducer & Description & Reference \\
\hline Calcium deficiency & $\begin{array}{l}\text { Correlation between necrosis and catalytic activity of superoxide dismutase in } \\
\text { Solanum tuberosum L. tubers }\end{array}$ & Monk-Talbot et al., 1991 \\
\hline Chilling & $\begin{array}{l}\text { Suggests resistant Lycopersicon hirsutum Humb. \& Bonpl. decreases production of active } \\
\text { oxygen species at low temperatures }\end{array}$ & Walker and McKersie, 199 \\
\hline Heat and light & $\begin{array}{l}\text { Decreased electron transport in Triticum aestivum L. leaves linked to peroxidation } \\
\text { of thylakoid lipids }\end{array}$ & Mishra and Singhal, 1992 \\
\hline \multirow[t]{2}{*}{ Microbial attack } & $\begin{array}{l}\text { Formation of free radicals in Solanum tuberosum L. tubers that are infected } \\
\text { with Erwinia carotovora }\end{array}$ & Deighton et al., 1992 \\
\hline & $\begin{array}{l}\text { Oxidative response is one of earliest signals in hypersensitive response } \\
\text { in Glycine max Merr. cells }\end{array}$ & Legendre et al., 1993 \\
\hline Paraquat $^{z}$ & $\begin{array}{l}\text { Increased activity of antioxidant enzymes in drought-resistant } \\
\text { Zea mays L. strain }\end{array}$ & Pastori and Trippi, 1993 \\
\hline Pollutants & $\begin{array}{l}\text { In vitro demonstration of ozone-induced damage to Populus maximowizii A. Henry } \\
\text { rubisco via membrane lipids }\end{array}$ & Landry and Pell, 1993 \\
\hline Water deficit & $\begin{array}{l}\text { Resistance capacity of lipid extracts to peroxidation are affected by drought in } \\
\text { Phaseolus vulgaris L. leaves }\end{array}$ & Ferrari-Iliou et al., 1993 \\
\hline Aging & $\begin{array}{l}\text { Suggests gradual accumulation of free-radical products in Solanum tuberosum } \mathrm{L} \text {. } \\
\text { tubers but not consistent with lipoxygenase }\end{array}$ & Kumar and Knowles, 1993 \\
\hline Senescence & $\begin{array}{l}\text { Increased lipid peroxidation products detected during senescence of } \\
\text { Petroselinum crispum Mill. leaves }\end{array}$ & Meir et al., 1992 \\
\hline
\end{tabular}

Table 2. Recent references that do not support a link between lipid peroxidation and plant tissue disorders.

\begin{tabular}{|c|c|c|}
\hline Inducer & Description & Reference \\
\hline$\overline{\text { Bisulfite }}$ & $\begin{array}{l}\text { Evidence of protein damage to photosystem II occurs before evidence of lipid peroxidation } \\
\text { in Phaseolus vulgaris L. leaves }\end{array}$ & Covello et al., 1989 \\
\hline Chilling & $\begin{array}{l}\text { Differences in sensitivity of Cucumis sativus L. leaves not explained on the basis of } \\
\text { vulnerability to superoxide or presence of SOD }\end{array}$ & Hodgson and Raison, 1991 \\
\hline Dehydration & $\begin{array}{l}\text { Degree of fatty acid unsaturation does not decrease and production of superoxide did not } \\
\text { increase in Helianthus annus L. seedling thylakoids }\end{array}$ & Sgherri et al., 1993 \\
\hline Light or methylviologen & $\begin{array}{l}\text { Elevated cystolic glutathione reductase in leaves of transgenic Nicotiana tabacum } \mathrm{L} \text {. } \\
\text { plants did not affect oxidative balance }\end{array}$ & Foyer et al., 1991 \\
\hline \multirow[t]{2}{*}{ Microbial attack } & $\begin{array}{l}\text { Oxidative burst in Trifolium repens L. and Nicotiana tabacum L. is independent of } \\
\text { phytoalexin production and hypersensitive response }\end{array}$ & Devlin and Gustine, 1992 \\
\hline & $\begin{array}{l}\text { Free radical scavenger tests indicate that } \cdot \mathrm{OH} \text { and LOX are not involved in stress ethylene } \\
\text { production of Glycine max Merr. cuttings }\end{array}$ & Pennazio and Roggero, 1992 \\
\hline Paraquat $^{2}$ & $\begin{array}{l}\text { Higher levels of chloroplast SOD in transgenic Nicotiana tabacum L. plants did not } \\
\text { prevent } \mathrm{O}_{2}^{-} \text {toxicity }\end{array}$ & Tepperman and Dunsmuir, 1990 \\
\hline \multirow[t]{3}{*}{ Aging } & No measurable loss of PUFA observed in Typha latifolia $\mathrm{L}$. pollen & van Bilsen and Hoekstra, 1993 \\
\hline & $\begin{array}{l}\text { Absence of LOX isozymes in transgenic Glycine max Merr. seeds did not increase } \\
\text { resistance to accelerated aging }\end{array}$ & Wang et al., 1990 \\
\hline & No free-radical accumulation associated with loss of viability of Triticum aestivum L. seeds & Girard and LeMeste, 1992 \\
\hline Senescence & $\begin{array}{l}\text { Tocopherol levels in Petroselinum sativum Mill. and Apium graveolens L. leaves do not } \\
\text { decrease predictably }\end{array}$ & Rise et al., 1989 \\
\hline
\end{tabular}

${ }^{2}$ Gramoxone(1,1'-dimethyl-4-4'-bypridinium ion) (paraquat).

phospholipid free radical and can be regenerated by the oxidation of ascorbic acid to dehydroascorbic acid (Buettner, 1993), which in turn can be regenerated by the oxidation of glutathione and additional oxidation-reduction reactions in the cell (Meister, 1992). In addition, glutathione protects protein thiols in the membrane in the presence and absence of $\alpha$-tocopherol (Palamanda and Kehrer, 1993). Note that since lipoxygenase produces lipid hydroperoxides directly without the free-radical intermediate (Gardner, 1991), lipoxygenase-catalyzed peroxidation does not lead directly to tocopheroxyl-radical formation. The action of lipoxygenase on lipids is also specific to the position of the double bond.

Lipid hydroperoxides increase the hydrophilic character of the internal bilayer (Frenkel, 1991). Relative to the active oxygen species and lipid radicals, lipid hydroperoxides are stable (Leshem, 1992), but they will degrade to undesirable free radicals (Schaich, 1992). Membrane repair systems have been identified that remove hydroperoxides by selective hydrolysis (Pacifici and Davies, 1991) and detoxify them by reactions coupled to glutathione reductase and nonspecific peroxidases (Salin, 1988).

In the absence of the necessary defense and repair systems, freeradical chain propagation of lipid peroxidation occurs within the membrane. As lipid hydroperoxides degrade, the lipid free radicals come into contact with other polyunsaturated fatty acids such that 10 to 100 additional lipid hydroperoxides are formed before the chain is broken (Niki et al., 1991). The rate of propagation is a factor of the interaction of lipid peroxyl radicals and polyunsaturated fatty acids in the membrane. This interaction is affected by both the concentration of available polyunsaturated fatty acids and the fluidity of the membrane. Although fluidity is frequently described in terms of chainordering, as affected by degree of unsaturation of fatty acids, rotational and lateral diffusion are more important factors in fluidity of membrane lipids (Carruthers and Melchior, 1988; Leshem, 1992; Webb and Green, 1991).

\section{A COMPREHENSIVE MODEL}

In the context of this view of lipid peroxidation, a model of peroxidative degradation of plant tissue can be constructed to explain the similarities and differences observed in plant tissue disorders. The model (Fig. 2) is offered to provide a basis for systematically testing the role of lipid peroxidation in the etiology of plant tissue disorders. It is consistent with most of the data collected to date, but has not been conclusively demonstrated.

Under normal conditions in the cell, active oxygen species are produced. Most of these species are scavenged or quenched by primary defense mechanisms, and little peroxidation of membrane lipids and proteins occurs. Any peroxidized lipids and proteins are quickly repaired. Upon exposure of plant tissue to stress, however, the level of active oxygen species tends to increase (Walker and McKersie, 1993). Stress may also induce the synthesis of defense molecules such as the antioxidant enzymes - superoxide dismutase, catalase, ascorbate peroxidase, and glutathione peroxidase (Mishra et al., 1993). Upon 

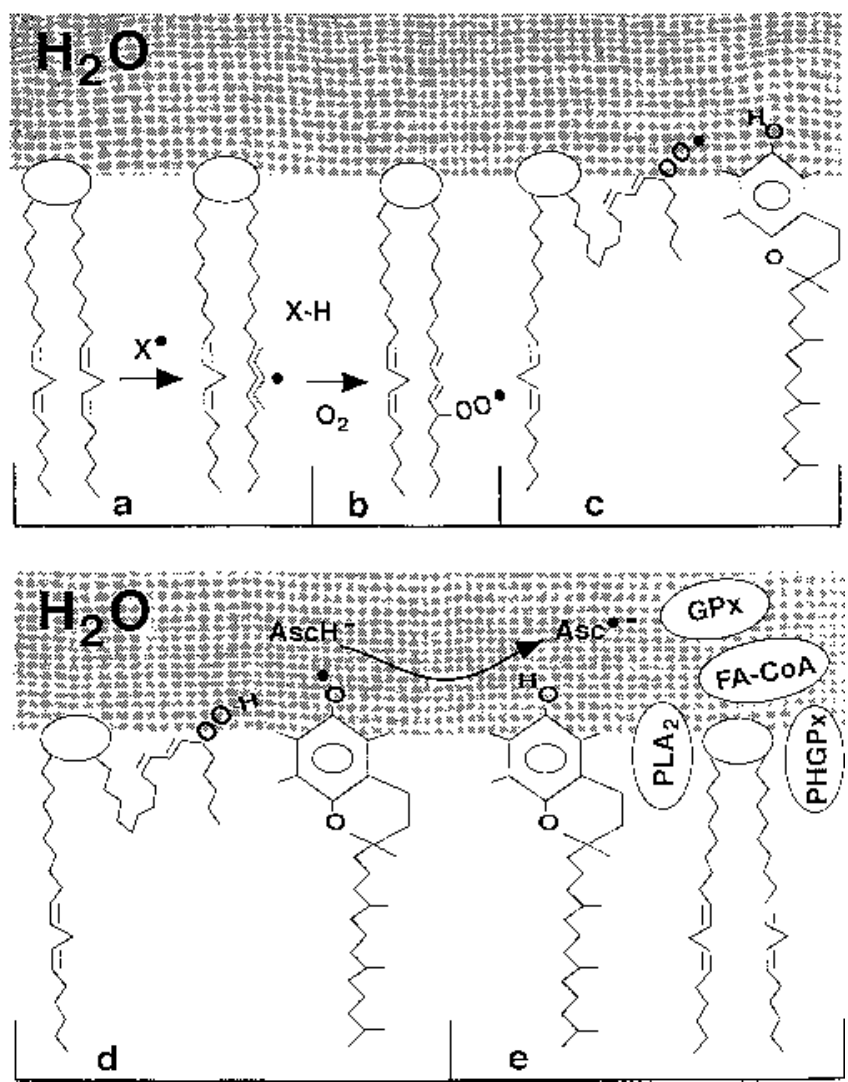

Fig. 1. Membrane lipid peroxidation. Only one leaflet of the bilayer is represented. (a) Initiation of the peroxidation process by an oxidizing radical, $\mathrm{X}$; by abstraction of a bis-allylic hydrogen, thereby forming a pentadienyl radical. (b) Oxygenation to form a peroxyl radical and a conjugated diene. (c) Peroxyl radical moiety partitions to the watermembrane interface where it is poised for repair by tocopherol. (d) Peroxyl radical is converted to a lipid hydroperoxide, and the resulting tocopherol radical can be repaired by ascorbate. (e) Tocopherol has been recycled by ascorbate; the resulting ascorbate radical can be recycled by enzyme systems. The enzymes phospholipase $\mathrm{A}_{2}\left(\mathrm{PLA}_{2}\right)$, phospholipid hydroperoxide glutathione peroxidase (PH-GPx), glutathione peroxidase (GPx), and fatty acyl-coenzyme A (FA-CoA) cooperate to detoxify and repair the oxidized fatty acid chain of the phospholipid. This cartoon cannot show the dynamic aspects of this process. Tocopherol (TOH) in the membrane will undoubtedly be bobbing "up and down" so that the position of the "OH" is variable. In addition, $\mathrm{TOH}$ and TO" may have somewhat differing positions at the interface. Reprinted from Archives of Biochemistry and Biophysics [Buettner (1993) 300:535-543] with permission.

prolonged exposure, however, the level of prooxidants can exceed the defense capacity of the cell, or a specific membrane in the cell, against peroxidative attack. The tipping of this balance from net defense to net peroxidation could result from a continued increase in prooxidant formation, a decrease in one or more of the primary defense mechanisms, or a combination of these events (Purvis and Shewfelt, 1993). Although lipids and proteins are subject to free-radical attack, lipid peroxidation is kinetically favored (Murphy et al., 1992). Thus, if the process is regulated strictly by kinetics, peroxidation of polyunsaturated fatty acids may serve a protective function to prevent direct attack on proteins. Evidence in some animal systems suggests that protein damage is incurred by direct attack (Pacifici and Davies, 1991).

As lipid free radicals are converted to lipid hydroperoxides, $\alpha$ tocopherol concentrations decrease, particularly when ascorbic acid, glutathione, and other cell reductants in contact with the affected membrane(s) are depleted. When the tocopherol concentration in the membrane is too low to protect the lipids, free-radical chain propagation occurs much faster than the repair mechanisms can function. Modification of the physical properties of the membrane (Bruch and Thayer, 1983) and direct peroxidation of proteins by lipid free radicals (Murphy et al., 1992) lead to decreased protein activity (Thomas et al.,
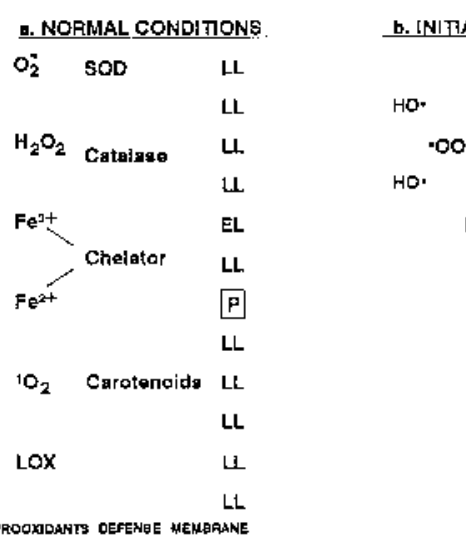

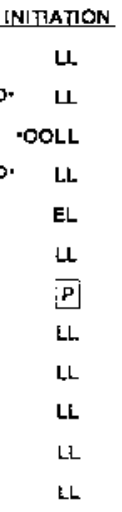

E. CHAIN-BLOCKING

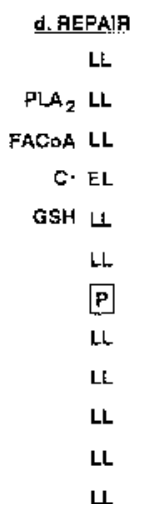

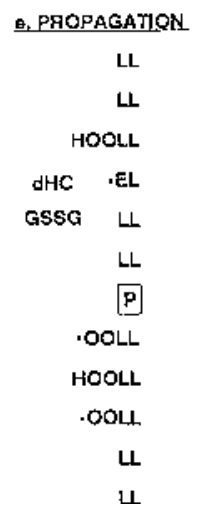

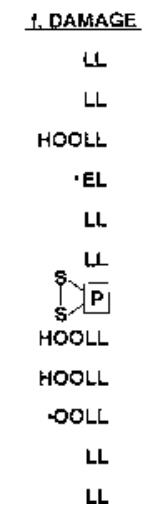

Fig. 2. A comprehensive model depicting free-radical attack of membrane lipids, initiation, chain-blocking, repair, propagation, and protein damage, where $\mathrm{O}_{2}^{-}$represents superoxide; $\mathrm{H}_{2} \mathrm{O}_{2}$, hydrogen peroxide; $\mathrm{Fe}^{3+}$, ferric iron; $\mathrm{Fe}^{2+}$, ferrous iron; ${ }^{1} \mathrm{O}_{2}$, singlet oxygen; LOX, lipoxygenase; SOD, superoxide dismutase; L, phospholipid molecule with two fatty acids; E, $\alpha$ tocopherol; $\mathrm{P}$, membrane-bound protein; $\mathrm{HO} \bullet$, hydroxyl radical; $\bullet \mathrm{OOLL}$, lipid peroxyl radical; HOOLL, lipid hydroperoxide; $\bullet$ E, tocopherol radical; $\mathrm{PLA}_{2}$, phospholipase $\mathrm{A}_{2} ; \mathrm{FACoA}$, fatty acyl coenzyme A; $\mathrm{C}$, ascorbic acid radical; GSH, glutathione; dHC, dehydroascorbic acid; GSSG, oxidized glutathione; $\bullet \mathrm{OL}$, lipid alkoxyl radical; and $\mathrm{S}>\mathrm{P}$, a protein with a disulfide bond at an active site implying damage. Under normal conditions, defense mechanisms protect the membrane from peroxidation. Initiation occurs when oxygen radicals, such as $\bullet \mathrm{OH}$, overcome the defense system to form -OOL (see Fig. $1 \mathrm{a}$ and b). Chain-blocking is achieved by $\alpha$-tocopherol forming HOOLL and $\bullet E$ (Fig. $1 \mathrm{c}$ and d). Repair occurs by cleavage of the radical to $\mathrm{C} \bullet$ (Fig. 1e). Propagation results upon depletion of enough E, C, and GSH such that $\bullet$ OOLL and HOOLL are formed more rapidly than repair mechanisms can be effective. Damage to proteins is incurred through interaction with an adjacent $\cdot$ OOLL

1989), metabolic imbalances, cellular dysfunction, and ultimately tissue disorders.

Although no comprehensive study of peroxidative degradation of a specific membrane has been conducted with respect to a specific disorder in a plant tissue, a wide range of studies supports specific steps in the proposed model. In addition to the evidence presented in Table 1 , increased superoxide generation has been noted in hypersensitive response (Adam et al., 1989; Keppler and Novacky, 1987). Formation of the hydroxyl radical in microsomes isolated from seedlings has been documented (Simontacchi and Puntarulo, 1992). Initial increases in the levels of antioxidant enzymes have been reported during winter hardening of red spruce (Picea rubeus Sarg.) (Doulis et al., 1993), of herbicide-treated leaves (Schmidt and Kunert, 1986), and in manganese-deficient plants exposed to high-intensity light conditions (Cakmak and Marschner, 1992). Decreases in levels of antioxidant enzymes have been reported during chilling of susceptible seedlings (Jahnke et al., 1991) and dehydration of germinating seeds (Leprince et al., 1990). Superoxide dismutase activity decreases in mitochondria of senescing petals while increasing in the peroxisomes of the same petals (Droillard and Paulin, 1990). Depletion of cellular, water-soluble antioxidants 
has been observed during hydration of seed axes (Senaratna et al., 1985) and chilling of susceptible fruit (Hariyadi and Parkin, 1991). Alpha-tocopherol levels decrease in thylakoids from chilled fruit before evidence of injury (Hariyadi and Parkin, 1991). Measurable levels of peroxidative products have been observed before symptom development of hypersensitive reaction (Adam et al., 1989) and loss of desiccation tolerance (Leprince et al., 1990). Evidence of lipidprotein peroxidative complexes detected by fluorescent pigment methodology has been described in senescing leaves (Meir et al., 1992) and chilled fruit (Hariyadi and Parkin, 1991).

\section{EXPLANATIONS}

A comprehensive model for lipid peroxidation as the primary cause of plant tissue disorders must explain contrary evidence, the wide variability of symptoms observed for a diverse set of stimuli, the delay between stress induction and evidence of peroxidation, cross protection observed between stress responses, localized damage as noted in hypersensitive reaction and chilling injury $(\mathrm{CI})$, and the enhancement of CI observed upon rewarming.

Evidence against lipid peroxidation as a causal agent in plant tissue disorders can be categorized by failure to observe an increase in a specific oxidative species (Sgherri et al., 1993), inability to relate sensitivity to stress on the basis of specific antioxidants or scavenging enzymes (Foyer et al., 1991; Hodgson and Raison, 1991; Rise et al., 1989; Tepperman and Dunsmuir, 1990), the lack of a relationship between lipoxygenase activity and the disorder (Pennazio and Roggero, 1992; Wang et al., 1990), and the lack of selective decreases in polyunsaturated fatty acids (Sgherri et al., 1993; van Bilsen and Hoekstra, 1993). The proposed model suggests that, rather than focusing on a single event (e.g., increase in an active oxygen species or decrease in activity of a specific enzyme), the overall balance between prooxidants and defense reactions must be studied. Much of the research has focused on superoxide production and superoxide dismutase defenses, but if superoxide dismutase is present and catalase is deficient then hydrogen peroxide could accumulate to toxic levels. In addition, compartmentation of enzymes and substrates in the cell, ignored by most of the studies cited in Tables 1 and 2, would be expected to affect the oxidative balance at a particular membrane site. For example, if superoxide is produced and is able to migrate to a membrane site outside compartments containing superoxide dismutase, the superoxide could be converted to the hydroxyl radical via the Haber-Weiss reaction, with damage incurred at cellular superoxide dismutase levels that appear to be sufficient for protection. Exposure of susceptible and resistant leaves to chilling conditions resulted in increases in production of active oxygen species and antioxidant enzyme activity in both species (Walker and McKersie, 1993). Decreased susceptibility was attributed to a more rapid decline in subsequent production of active oxygen species in the resistant species, supporting the suggestion that an understanding of the balance of prooxidants and defense mechanisms is the critical area of study in lipid peroxidation research.

The proposed model is based on the premise that damage to a single membrane system (e.g., plasma membrane, thylakoid, inner mitochondrial membrane) in the cell is sufficient to induce metabolic disorders and tissue injury. Thus, measurement of total cellular polyunsaturated fatty acids may not reveal significant losses of polyunsaturated fatty acids in the affected membrane. The model is based on initiation and propagation of lipid free radicals in the membrane and considers formation of the hydroxyl radical in the presence of $\mathrm{Fe}^{2+}$, $\mathrm{Fe}^{3+}$, and singlet oxygen to be primary initiators of peroxidative degradation in plant membranes. Lipoxygenase is probably not a major factor in causing these disorders. Transgenic soybean seeds with decreased lipoxygenase were not more resistant to accelerated aging (Wang et al., 1990). More likely, however, hydrolytic enzymes and lipoxygenase are part of a programmed turnover or retailoring mechanism rather than being responsible for membrane degradation and resultant tissue disorders.

In this model, the wide variability in response and symptom development in diverse types of plant tissue to the same stress or similar types of tissue to various stresses is attributed to differences in loss of protein function (e.g., ion transport, enzyme activity) in the membrane that is the site of attack. Studies on CI have shown differences in susceptibility of organs as influenced by genotype (Bodner and Larcher, 1978) as well as differences in susceptibility of specific membranes in a cell (Cheng and Shewfelt, 1988; Marangoni et al., 1989). The development of symptoms would result from the specific metabolic imbalances incurred by disruption of specific enzymes in the affected membrane or loss of membrane permeability. While the membrane site of attack would vary from tissue to tissue and potentially from stress to stress, the membrane of greatest susceptibility to a specific stress within a particular organ should always be the same, and response, including symptom development, should be predictable based on the function of that particular membrane in that cell in that particular organ.

The delay between stress induction and evidence of peroxidation can be explained by a greater understanding of the peroxidation process. Comparing the rate of reaction of active oxygen species occurring within nanoseconds or microseconds (Buettner, 1993) and the development of symptoms measured in hours (Adam et al., 1989), days (Cakmak and Marschner, 1992; Jahnke et al., 1991; Leprince et al., 1990), or weeks (Cheng and Shewfelt, 1988) suggests that the process is slow and incremental. Most of the peroxidation products measured as thiobarbituric acid-reactive substances (TBA-RS) and fluorescent pigments would not be expected to accumulate until late in the response process, probably during the propagation stage (Winston, 1990) and then only in the affected membrane. Thus, it should not be surprising that, in some tissues, evidence of these types of peroxidation could coincide with evidence of injury. Earlier measures of peroxidation, such as the presence of conjugated dienes, changes in electron spin resonance (ESR), and depletion of $\alpha$-tocopherol or $\beta$-carotene in the affected membrane, should precede evidence of symptoms.

Mitigating treatments, such as cold acclimation (Doulis et al., 1993; Shewfelt, 1992), temperature conditioning (Hatton, 1990), and cross protection from one stress to another (Lurie et al., 1991; Shaaltiel et al., 1988), are attributed in this model to induction of defense mechanisms in the susceptible membrane at sublethal levels of stress exposure. Likewise, localized responses observed in hypersensitive reaction (Keppler and Novacky, 1987) and pitting, a symptom of CI in many fruits (Hatton, 1990; Jackman et al., 1988), may represent signaling from cells that are directly affected, permitting adjacent cells to synthesize new antioxidants to prevent injury. Thus, those cells exposed to direct microbial attack or earlier exposure to low temperatures within microclimates would induce defense mechanisms in adjacent cells, enabling them to survive.

One of the striking features of CI in harvested products is that symptoms not evident during chilling exposure develop rapidly upon rewarming (Jackman et al., 1988). If chilling is prolonged, however, symptoms usually will appear. A potential explanation for this phenomenon is that lipid hydroperoxides formed are stable enough at low temperatures that defense and repair processes present are sufficient to prevent propagation. As the temperature is raised, however, the breakdown of preformed lipid hydroperoxides in the affected membrane could occur more rapidly than the recovery of defense and repair mechanisms.

\section{IMPLICATIONS OF THE MODEL}

If the proposed model provides an accurate view of changes in the cell in response to the conditions described, we must change our view of stress physiology in plant tissue. The model as proposed suggests that 1) chemical processes in the membrane play a more direct role in development of disorders than biochemical (enzymic) processes; 2) the common link between many, if not all, membrane-associated disorders is free-radical propagation in the most susceptible membrane; 3 ) the critical oxidative process and susceptible membrane are nonspecific in plant response to stress but specific and predictable within a particular organ in response to a specific stress; and 4) headgroup mobility is as important as degree of fatty acid unsaturation in the development of these disorders.

One difficulty in conducting lipid peroxidation research is the lack of specificity of key antioxidants. Ascorbate, $\beta$-carotene, glutathione, 
and $\alpha$-tocopherol are all multifunctional (Winston, 1990). Thus, the effects on peroxidation of adding any of these compounds cannot be attributed to a single function. This lack of specificity of these molecules implies that the reaction kinetics in nonenzymic processes are at least as important as their role in enzyme-catalyzed reactions (Reed, 1990). Many of the primary defense reactions are enzymic in nature, such as those catalyzed by superoxide dismutase and catalase, as well as some repair reactions catalyzed by ascorbate peroxidase, glutathione reductase, and hydrolytic enzymes. These enzymes represent the ability of a cell to respond to increased levels of peroxidation. The disorder develops, however, as chemical reactions in a cell occur more rapidly than one or more of the critical enzymes is able to respond at the site. Thus, the breaching of the defense and repair mechanisms at the most susceptible membrane could be the result of a deficiency in a limiting enzyme, and that critical enzyme could vary from tissue to tissue. Genetic manipulation to control these disorders will require identifying the particular critical defense enzyme in the tissue studied. Overexpression of a critical enzyme might not alleviate the disorder if more than one enzyme is limiting. Also, much emphasis in membraneassociated disorders has been placed on membrane fluidity, usually with respect to chain ordering as determined by fatty acid unsaturation (Shewfelt, 1992; Webb and Green, 1991). If free-radical propagation is the critical step in the process as proposed in the model, then physical interactions of lipid free radicals with other polyunsaturated fatty acids would be as important as the concentration of the polyunsaturated fatty acids. Lateral and rotational diffusion, as controlled by the mobility of the lipid headgroup, plays a major role in fatty acid interaction within the membrane (Carruthers and Melchior, 1988; Leshem, 1992).

The importance of compartmentation within the cell cannot be overemphasized (Elstner, 1991; Schaich, 1992). The model suggests that a single membrane within the cell might be attacked, leading to dysfunction and even cell death. Thus, localized defense and repair or lack of defense and repair could be critical in the prevention or development of a disorder. Zhu and Scandalios (1992) demonstrated increased resistance to oxidative stress by increasing Mn superoxide dismutase expression, confined to mitochondria, in a deficient yeast strain.

This model provides a framework for systematically testing the role of membrane lipid peroxidation in the etiology of plant tissue disorders. It implies that future work must be directed at the specific membrane that is being attacked rather than at cellular membranes as a whole. Modifying genes either to limit production of active oxgyen species or to increase synthesis of an antioxidant enzyme should not be attempted without prior or concurrent identification of the primary site of attack and the factor(s) causing the imbalance leading to net peroxidation. The causal factor(s) should be the target of the genemodification studies. In addition to measuring products of lipid peroxidation, studies should also follow disappearance of antioxidants, such as $\alpha$-tocopherol and carotenoids, associated with the membrane of interest as well as cellular reductants, such as ascorbic acid and glutathione, to determine whether depletion precedes evidence of peroxidation. Furthermore, developing better means of assessing the progress of peroxidation in vivo is essential. Future studies expected to contribute to our understanding of peroxidative degradation of membranes include those that 1) can successfully partition healthy and unhealthy domains of cells within tissue that has been exposed to a specific stress and 2) provide an evolution of peroxidative degradation by histochemistry.

\section{Literature Cited}

Adam, A., T. Farkas, G. Somlyai, M. Hevesi, and Z. Kiraly. 1989. Consequence of $\mathrm{O}_{2}^{-}$generation during a bacterially induced hypersensitive reaction in tobacco: Deterioration of membrane lipids. Physiol. Mol. Plant Pathol. 34:13-26.

Bodner, M. and W. Larcher. 1987. Chilling susceptibility of different organs and tissues of Saintpaulia ionatha and Coffea arabica. Agnew. Botanik. 61:225-242.

Borg, D.C. and K.M. Schaich. 1988. Iron and hydroxyl radicals in lipid oxidation: Fenton reactions in lipid and nucleic acids co-oxidized with lipid, p. 427-441. In: P.A. Cerutti, I. Fridovich, and J.M. McCord (eds.).
Oxy-radicals in molecular biology and pathology. Alan R. Liss, New York. Bradley, D.G. and D.B. Min. 1992. Singlet oxygen oxidation of foods. Crit. Rev. Food Sci. Nutr. 31:211-236.

Bruch, R.C. and W.S. Thayer. 1983. Differential effect of lipid peroxidation on membrane fluidity as determined by electron spin resonance probes. Biochim. Biophys. Acta. 733:216-222.

Buettner, G.R. 1993. The pecking order of free radicals and antioxidants: Lipid peroxidation, $\alpha$-tocopherol, and ascorbate. Arch. Biochem. Biophys. 300:535-543.

Cabrini, L., B. Pasquali, B. Tadolini, A.M. Sechi, and L. Landi. 1986. Antioxidant behavior of ubiquinone and $\beta$-carotene incorporated in model membranes. Free Radical Res. Commun. 2:85-92.

Cakmak, I. and H. Marschner. 1992. Magnesium deficiency and high light intensity enhanced activities of superoxide dismutase, ascorbate peroxidase, and glutathione reductase in bean leaves. Plant Physiol. 98:12221227.

Carruthers, A. and D.L. Melchior. 1988. Role of bilayer lipids in governing membrane transport processes, p. 201-225. In: R.C. Aloia, C.C. Curtain, and L.M. Gordon (eds.). Lipid domains and the relationship to membrane function. Alan R. Liss, New York.

Chakraborty, N. and B.C. Tripathy. 1992. Involvement of singlet oxygen in 5aminolevolinic acid-induced photodynamic damage of cucumber (Cucumis sativus L.) chloroplasts. Plant Physiol. 98:7-11.

Cheng, T.-S. and R.L. Shewfelt. 1988. The effect of chilling exposure of tomatoes during subsequent ripening at ambient temperature. J. Food Sci. 53:1160-1162

Cogrel, P., et al. 1993. The relationship between fatty acid peroxidation and $\alpha-$ tocopherol consumption in isolated normal and transformed hepatocytes. Lipids 28:115-119.

Covello, P.S., A. Chang, E.B. Dumbroff, and J.E. Thompson. 1989. Inhibition of photosystem II precedes thylakoid membrane lipid peroxidation in bisulfite-treated leaves in Phaseolus vulgaris. Plant Physiol. 90:14921497.

Deighton, N., D.J. Johnston, S.M. Glidewell, G.D. Lyon, and B.A. Goodman 1992. The involvement of oxygen-derived free radicals in the resistant response of potato tubers to Erwinia carotovora. Protoplasma 171:167169.

Devlin, W.S. and D.L. Gustine. 1992. Involvement of the oxidative burst in phytoalexin accumulation and the hypersensitive response. Plant Physiol. 100:1189-1195.

DiMascio, P., S. Kaiser, and H. Sies. 1989. Lycopene as the most efficient biological carotenoid singlet oxygen quencher. Arch. Biochem. Biophys. 274:532-538.

Doulis, A.G., et al. 1993. Antioxidant response and winter hardiness in red spruce (Picea rubens, Sarg.). New Phytol. 123:365-374.

Droillard, M.-J. and A. Paulin. 1990. Isozymes of superoxide dismutase in mitochondria and peroxisomes isolated from petals of carnation (Dianthus caryophyllus) during senescence. Plant Physiol. 94:1187-1192.

Elstner, E.F. 1991. Mechanisms of oxygen activation in different compartments of plant cells, p. 13-25. In: E.J. Pell and K.L. Steffen (eds.). Active oxygen/oxidative stress and plant metabolism. Amer. Soc. Plant Physiol., Rockville, Md.

Ferrari-Iliou, R., et al. 1993. In vitro phytodynamic lipid peroxidation of total lipophilic extracts from leaves of bean plants. Biochim. Biophys. Acta 1166:48-54.

Frenkel, C. 1991. Disruption of macromolecular hydration-A possible origin of chilling destabilization of biopolymers. Trends Food Sci. Technol. 2:3941

Foyer, C., M. Lelandais, C. Galap, and K.J. Kunert. 1991. Effects of elevated cytosolic glutathione reductase activity on the cellular glutathione pool and photosynthesis in leaves under normal and stress conditions. Plant Physiol. 97:863-872.

Gardner, H.W. 1991. Recent investigations into the lipoxygenase pathway of plants. Biochim. Biophys. Acta. 1084:221-239.

Girard, J. and M. LeMeste. 1992. Lack of relationship between free radical levels determined by ESR technique and viability of wheat seeds. C.R. Acad. Sci. Paris 314, Ser. III:417-422.

Hariyadi, P. and K.L. Parkin. 1991. Chilling-induced oxidative stress in cucumber fruits. Postharvest Biol. Technol. 1:33-45.

Hatton, T.T. 1990. Reduction of chilling injury with temperature manipulation, p. 270-280. In: C.-Y. Wang (ed.). Chilling injury of horticultural crops. CRC Press, Boca Raton, Fla

Hildebrand, D.F. 1989. Lipoxygenases. Physiol. Plant. 76:249-253.

Hodgson, R.A.J. and J.K. Raison. 1991. Lipid peroxidation and superoxide dismutase activity in relation to photoinhibition induced by chilling in moderate light. Planta 185:215-219.

Jackman, R.L., R.Y. Yada, A. Marangoni, K.L. Parkin, and D.W. Stanley. 1988 Chilling injury. A review of quality aspects. J. Food Qual. 11:253-278.

Jahnke, L.S., M.R. Hull, and S.P. Long. 1991. Chilling stress and oxygen 
metabolizing enzymes in Zea mays and Zea diploperennis. Plant Cell Environ. 14:97-104.

Kane, D.J., et al. 1993. Bco-2 inhibition of neural death: Decreased generation of reactive oxygen species. Science 262:1274-1277.

Kehrer, J.P. 1993. Free radicals as mediators of tissue injury and disease. Crit. Rev. Toxicol. 23:21-48.

Keppler, L.D. and A. Novacky. 1987. The initiation of membrane lipid peroxidation during bacteria-induced hypersensitive reaction. Physiol. Mol. Plant Pathol. 30:233-245.

Kumar, G.N.M. and N.R. Knowles. 1993. Changes in lipid peroxidation and lipolytic free-radical scavenging enzyme activities during aging and sprouting of potato (Solanum tuberosum) seed-tubers. Plant Physiol. 102:115-124.

Landry, L.G. and E.J. Pell. 1993. Modification of rubisco and altered proteolytic activity of $\mathrm{O}_{3}$-stressed hybrid poplar (Populus maximowizii $\mathrm{X}$ trichoeanpa). Plant Physiol. 101:1355-1362.

Legendre, L., S. Rueter, P.F. Heinstein, and P.S. Low. 1993. Characterization of the oligogalacturonide-induced oxidative burst in cultured soybean (Glycine max) cells. Plant Physiol. 102:233-240.

Leprince O., R. Deltour, P.C. Thorpe, N.M. Atherton, and G.A.F. Hendry. 1990. The role of free radicals and radical processing systems in loss of desiccation tolerance in germinating maize (Zea mays L.). New Phytol. 116:573-580.

Leshem, Y.Y. 1992. The plant membrane: A biophysical approach to structure, development and senescence. Kluwer Press, Amsterdam, The Netherlands.

Lurie, S., J.D. Klein, and R. Ben Arie. 1991. Prestorage heat treatment delays superficial scald on 'Granny Smith' apples. HortScience 26:166-167.

Marangoni, A.G., A.K. Smith, R.Y. Yada, and D.W. Stanley. 1989. Ultrastructural changes associated with chilling injury in mature-green tomato fruit. J. Amer. Soc. Hort. Sci. 114:958-962.

Mead, J.F. 1976. Free radical mechanisms of lipid damage and consequences for cellular membranes, p. 51-68. In: W.A. Pryor (ed.). Free radicals in biology. vol. 1. Academic, New York.

Meir, S., S. Philosoph-Hadas, and N. Aharoni. 1992. Ethylene-increased accumulation of fluorescent lipid-peroxidation products detected during senescence of parsley by a newly developed method. J. Amer. Soc. Hort. Sci. 117:128-132.

Meister, A. 1992. On the antioxidant effects of ascorbic acid and glutathione. Biochem. Pharmacol. 44:1905-1915.

Minotti, G. and S.D. Aust. 1992. Redox cycling of iron and lipid peroxidation. Lipids 27:219-226.

Mishra, P.M., R.K. Mishra, and G.S. Singhal. 1993. Changes in the activities of anti-oxidant enzymes during exposure of intact wheat leaves to strong visible light at different temperatures in the presence of protein synthesis inhibitors. Plant Physiol. 102:903-910.

Mishra, R.K. and G.S. Singhal. 1992. Function of photosynthetic apparatus of intact wheat leaves under high light and heat stress and its relationship with peroxidation of thylakoid lipids. Plant Physiol. 98:1-6.

Monk-Talbot, L.S., H.V. Davies, M. Macaulay, and M.P. Foster. 1991. Superoxide dismutase and susceptibility of potato (Solanum tuberosum L.) tubers to calcium related disorders. J. Plant Physiol. 137:499-501.

Murphy, M.E., H. Scholich, and H. Sies. 1992. Protection by glutathione and other thiol compounds against the loss of protein thiols and tocopherol homologs during microsomal lipid peroxidation. Eur. J. Biochem. 210:139146.

Niki, E., Y. Yamamoto, E. Kamuro, and K. Sato. 1991. Membrane damage due to lipid oxidation. Amer. J. Clin. Nutr. 53:2015-2055.

Pacifici, R.E. and K.J.A. Davies. 1991. Protein, lipid and DNA repair systems in oxidative stress: The free radical theory of aging revisited. Gerontology 37:166-180.

Palamanda, J.R. and J.P. Kehrer. 1993. Involvement of vitamin E and protein thiols in the inhibition of microsomal lipid peroxidation by glutathione. Lipids 28:427-431.

Pastori, G.M. and V.S. Trippi. 1993. Antioxidative protection in a droughtresistant maize strain during leaf senescence. Physiol. Plant. 87:227-231.

Pennazio, S. and P. Roggero. 1992. Effects of free radical scavengers on stress ethylene in soybean leaves hypersensitively reacting to tobacco necrosis virus. Ann. Bot. 69:437-439.

Purvis, A.C. and R.L. Shewfelt. 1993. Does the alternative pathway ameliorate chilling injury in sensitive plant tissues? Physiol. Plant. 88:712-718.

Reed, G.A. 1990. Co-oxidation of environmental toxic agents by lipid peroxyl species, p. 155-180. In: C. Vigo-Pelfrey (ed.). Membrane lipid oxidation. vol. 1. CRC Press, Boca Raton, Fla.

Rise, M., M.Cojocaru, H.E. Gottlieb, and E.E. Goldschmidt. 1989. Accumulation of a-tocopherol in senescing organs as related to chlorophyll degradation. Plant Physiol. 89:1028-1030.

Salin, M.L. 1988. Toxic oxygen species and protective systems of the chloroplast. Physiol. Plant. 72:681-689.

Schaich, K.M. 1992. Metals and lipid oxidation. Contemporary issues. Lipids 27:209-218.
Schmidt, A. and K.J. Kunert. 1986. Lipid peroxidation in higher plants-The role of glutathione reductase. Plant Physiol. 82:700-702.

Senaratna, T., B.D. McKersie, and R.H. Stinson. 1985. Antioxidant levels in germinating soy-bean seed axes in relation to free radical and dehydration tolerance. Plant Physiol. 78:168-171.

Sgherri, C.L.M., C. Pinzino, and F. Navari-Izzo. 1993. Chemical changes and $\mathrm{O}_{2}^{-}$production in thylakoid membranes under water stress. Physiol. Plant. 87:211-216.

Shaaltiel, Y., A. Glazer, P.F. Bocion, and J. Gressel. 1988. Cross tolerance to herbicidal and environmental oxidants of plant biotypes tolerant to paraquat, sulfur dioxide, and ozone. Pesticide Biochem. Physiol. 31:13-23.

Shewfelt, R.L. 1992. Response of plant membranes to chilling and freezing, p. 192-219. In: Y.Y. Leshem (ed.). The plant membrane: A biophysical approach to structure, development and senescence. Kluwer Press, Amsterdam, The Netherlands.

Shewfelt, R.L. and M.C. Erickson. 1991. Role of lipid peroxidation in the mechanism of membrane-associated disorders in edible plant tissue. Trends Food Sci. Technol. 2:152-154.

Simontacchi, M. and S. Puntarulo. 1992. Oxygen radical generation by isolated microsomes from soybean seedlings. Plant Physiol. 100:1263-1268.

Tepperman, J.M. and P. Dunsmuir. 1990. Transformed plants with elevated levels of chloroplastic SOD are not more resistant to superoxide toxicity. Plant Mol. Biol. 14:501-511.

Thomas, S.M., G.M. Gebiki, and R.T. Dean. 1989. Radical initiated $\alpha$ tocopherol depletion and lipid peroxidation in mitochondrial membranes. Biochim. Biophys. Acta. 1002:189-197.

Urano, S., et al. 1993. Mobility and molecular orientation of vitamin $\mathrm{E}$ in liposomal membranes as determined by ${ }^{19} \mathrm{~F}$ NRM and fluorescence polarization techniques. Arch. Biochem. Biophys. 303:10-14.

van Bilsen, D.G.J.L. and F.A. Hoekstra. 1993. Decreased membrane integrity in aging Typha latifolia L. pollen. Plant Physiol. 101:675-682.

Walker, M.A. and B.D. McKersie. 1993. Role of the ascorbate-glutathione antioxidant system in chilling resistance of tomato. J. Plant Physiol. 141:234-239.

Wang, J., K. Fujimoto, T. Miazawa, Y. Endo, and K. Kitamura. 1990. Sensitivities of lipoxygenase-lacking soybean seeds to accelerated aging and their chemiluminescence levels. Phytochemistry 29:3739-3742.

Webb, M.S. and B.R. Green. 1991. Biochemical and biophysical properties of thylakoid acyl lipids. Biochim. Biophys. Acta 1060:133-158.

Winston, G.W. 1990. Physicochemical basis for free radical formation in cells: Production and defenses. In: R.G. Alscher and J.R. Cumming (eds.). Stress response in plants: Adaptation and acclimation mechanisms. Wiley-Liss, New York.

Zhu, D. and J.G. Scandalios. 1992. Expression of the maize MnSOD (SOD 3) gene in MnSOD-deficient yeast rescues the mutant yeast under oxidative stress. Genetics 131:803-809. 